\title{
BAKTERIOBÓJCZA AKTYWNOŚĆ KOLOIDÓW SREBRA STABILIZOWANYCH HYDROLIZATAMI SKROBIOWYMI ORAZ ICH WPŁYW NA WYTRZYMAŁOŚĆ ZAPRAW CEMENTOWYCH
}

\author{
Marta Sybis $^{1}$, Emilia Konował ${ }^{2}$, Anna Modrzejewska-Sikorska ${ }^{2}$ \\ ${ }^{1}$ Wydział Inżynierii Środowiska i Gospodarki Przestrzennej, Uniwersytet Przyrodniczy w Poznaniu, Poznań \\ ${ }^{2}$ Wydział Technologii Chemicznej, Politechnika Poznańska, Poznań
}

\begin{abstract}
STRESZCZENIE
W artykule przeanalizowano koloidy srebra stabilizowane hydrolizatami skrobiowymi pod kątem właściwości bakteriobójczych, określając również ich wielkość oraz kształt. Zbadano także właściwości wytrzymałościowe zapraw cementowych z domieszkami analizowanych hydrolizatów skrobiowych, lignosulfonianów sodowych i ich połączenia $\mathrm{z}$ nanosrebrem. Koloidy srebra poddano analizie spektrofotometrycznej UV-vis w celu stwierdzenia obecności nanostruktur srebra. Określono również rozkład wielkości nanocząstek metodą nieinwazyjnego wstecznego rozproszenia światła oraz ich kształt za pomocą mikroskopii elektronowej (TEM). Otrzymane koloidy srebra podczas wykonania prób bakteriobójczych wykazały silną odporność na działanie tzw. bakterii bytowych. Połączenie wymienionych właściwości nanosrebra z właściwościami uplastyczniającymi plastyfikatorów daje możliwość wytwarzania zapraw cementowych i betonów odpornych na działanie mikroorganizmów o zwiększonej urabialności i wytrzymałości na ściskanie.
\end{abstract}

Słowa kluczowe: zaprawa cementowa, nanocząstki srebra, bakteriobójczość, dekstryna, wytrzymałość na ściskanie

\section{WSTĘP}

Srebro zalicza się do najstarszych w dziejach ludzkości środków bakteriobójczych. Już w starożytności Fenicjanie podczas swoich podróży przechowywali żywność w srebrnych pojemnikach, zabezpieczając tym samym produkty przed szybkim zepsuciem. W antycznym Rzymie srebro traktowane było jako środek leczniczy. Rany bitewne najwyższej rangi legionistów były okładane srebrnymi monetami, które przyspieszały ich gojenie. Bakteriobójczy mechanizm działania srebra był wówczas uznawany za magię czy też cud (Sagripanti, 1992; Alexander, 2009; Spear, 2010; Kanematsu i Yoshitake, 2015).

Przedrostek nano jest używany do wskazania jednej miliardowej części metra. Termin nanotechnologia został wymyślony przez profesora Norio Taniguchi z Tokyo University of Science w 1974 roku, aby opisać precyzję produkcji materiałów na poziomie nanometrów. Komisja Europejska przyjęła, że do nanotechnologii zalicza się wszystkie działania do wymiarów $100 \mathrm{~nm}$. W języku greckim nano znaczy karzeł, czyli coś ekstremalnie małego. W dzisiejszych czasach rozwój nanotechnologii jest bardzo optymistyczny, ponieważ nanocząstki metaliczne są najbardziej obiecujące ze względu na właściwości antybakteryjne (Rai, Yadav

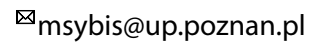


Sybis, M., Konował, E., Modrzejewska-Sikorska, A. (2017). Bakteriobójcza aktywność koloidów srebra stabilizowanych hydrolizatami skrobiowymi oraz ich wpływ na wytrzymałość zapraw cementowych. Acta Sci. Pol. Architectura, 16 (4), 37-46. doi: 10.22630/ASPA.2017.16.4.04.

i Gade, 2009). Takie materiały charakteryzują się odmiennymi właściwościami fizykochemicznymi niż ich odpowiedniki w makroskali, a nawet w mikroskali.

Nanostruktury niektórych pierwiastków, jak np. złota, srebra, miedzi, selenu, wykazują silne właściwości bakteriobójcze oraz grzybobójcze, są zatem stosowane w wielu dziedzinach nauki i przemysłu. Szczególne zainteresowanie wzbudziły nanocząstki srebra (AgNPs - ang. silver nanoparticles). Badania wykazują, że działanie bakteriobójcze AgNPs występuje nawet przy bardzo niskich stężeniach, co może być spowodowane dużą reaktywnością związaną z małym rozmiarem cząstek i dużą powierzchnią oddziaływania z bakteriami (Cho, Park, Osaka i Park, 2005; Oleszkiewicz, Korzekwa i Bugia-Płoskońska, 2008; Petica, Gavriliu, Lungu, Buruntea i Panzaru, 2008; Mirzajani, Ghassempour, Aliahmadi i Esmaeili, 2011). Autorzy powyższych prac udowodnili, że wraz ze zmniejszaniem wielkości nanocząstek rośnie ich aktywność bakteriobójcza.

Materiały, które są odporne na działanie mikroorganizmów, zyskują również ogromne zainteresowanie w budownictwie. W celu ochrony antybakteryjnej, najczęściej stosuje się skomplikowane i drogie nanoszenie powłok zawierających struktury nanosrebra, m.in. na powierzchnie betonowe. Powierzchnie te szybko ulegają zużyciu pod wpływem niesprzyjających warunków i istnieje konieczność ich ciągłego odnawiania. Rozwiązanie polegające na wprowadzeniu koloidów nanosrebra do całej objętości betonu mogłoby być niezwykle użyteczne.

Tradycyjne metody otrzymywania nanostrukturalnego srebra są powoli wypierane przez przyjazną dla środowiska, tzw. zieloną syntezę (Rauwel, Rauwel, Ferdov i Singh, 2015). Ostatnie dziesięciolecie przyniosło znaczący wzrost zainteresowania wytwarzaniem nanostruktur metali szlachetnych z użyciem bioreduktorów jonów metali i/lub biostabilizatorów układów.

Generalnie nanostruktury metali szlachetnych otrzymuje się poprzez chemiczną redukcję soli metalu. Duża energia powierzchniowa wytworzonych nanostruktur sprawia, że są one niezwykle reaktywne, przez co ulegają agregacji i wytrącają się z roztworów. Aby temu zapobiec, stosuje się różnego typu stabilizatory. Do wytworzenia metali w formie nanocząsteczek konieczne jest więc zastosowanie w procesie syntezy reduktora i stabilizatora. W pewnych sytuacjach jeden związek może służyć zarówno jako reduktor, jak i środek stabilizujący, np. lignosulfoniany, polisacharydy (Milczarek, Rebis i Fabianska, 2013; Konował, Modrzejewska-Sikorska i Milczarek, 2015).

Powszechne występowanie biopolimerów w przyrodzie, małe koszty ich pozyskiwania, biokompatybilność, biodegradowalność sprawiają, że biomateriały są stosowane do produkcji AgNPs. Biopolimery zbudowane na bazie peptydów (żelatyny, glutationu, keratyny) lub polisacharydów (alginianu, chitozanu, skrobi) są dobrymi środkami redukującymi jony srebra (Raveendran i Wallen, 2005; Szabó, Mihály, Sajó, Telegdi i Nyikos, 2014). Mechanizm powstawania AgNPs z udziałem węglowodanów został opisany przez Shervaniego i Yamamoto (Shervani i Yamamoto, 2011). Będące produktami kwasowej hydrolizy skrobi dekstryny są zbudowane z łańcuchów glukozowych o różnej długości. Zakłada się, że reakcja z jonami metalu zachodzi jedynie na końcach redukcyjnych biopolimeru, a łańcuchy sacharydowe pełnią rolę stabilizatorów. Mechanizm powstawania nanostruktur srebra stabilizowanych lignosulfonianami został opisany przez Milczarka i innych (2013).

Analiza najnowszej światowej literatury sugeruje, że koloidy srebra (nanosrebro + stabilizator) są aktywne biologicznie. Założono zatem, że zastosowanie nanostrukturalnego srebra stabilizowanego hydrolizatami skrobiowymi jako dodatku do zapraw cementowych powinno umożliwić uzyskanie materiałów, które charakteryzują się zwiększoną odpornością na niekorzystne działanie mikroorganizmów, a poprzez zastosowanie go jako stabilizatora plastyfikatorów również lepszą urabialność i większą wytrzymałość na ściskanie.

Celem badań była ocena właściwości fizykochemicznych koloidów srebra stabilizowanych hydrolizatami skrobiowymi (dekstrynami) oraz określenie aktywności bakteriobójczej wytworzonych koloidów srebra.

Ponadto zbadano wpływ dodatku samych plastyfikatorów (w postaci dekstryn i lignosulfonianu sodu) oraz plastyfikatorów z nanosrebrem na wytrzymałość zapraw cementowych. 
Sybis, M., Konował, E., Modrzejewska-Sikorska, A. (2017). Bakteriobójcza aktywność koloidów srebra stabilizowanych hydrolizatami skrobiowymi oraz ich wpływ na wytrzymałość zapraw cementowych. Acta Sci. Pol. Architectura, 16 (4), 37-46. doi: 10.22630/ASPA.2017.16.4.04.

\section{MATERIAL I METODY}

\section{Hydrolizaty skrobiowe oraz lignosulfoniany sodowe}

W badaniach wykorzystano plastyfikatory w postaci hydrolizatów skrobiowych oznaczonych jako HS1-HS5, lignosulfonianu sodowego (firmy MC-Bauchemie) oraz koloidy srebra stabilizowane wymienionymi wcześniej plastyfikatorami. Zastosowane hydrolizaty różniły się między sobą lepkością, kolorem, wilgotnością oraz metodą wytwarzania. Właściwości fizykochemiczne wykorzystywanych hydrolizatów skrobiowych przedstawiono w tabeli 1.

Tabela 1. Parametry fizykochemiczne hydrolizatów skrobiowych

Table 1. Physicochemical parameters of starch hydrolysates

\begin{tabular}{ccccc}
\hline Nazwa - Name & Typ - Type & $\begin{array}{c}\text { Wilgotność - Moisture } \\
{[\%]}\end{array}$ & $\begin{array}{c}\text { Wartość pH 1\% roztworu } \\
\text { pH value of 1\% solution }\end{array}$ & $\begin{array}{c}\text { Lepkość - Viscosity } \\
{[\text { Pa·s }]}\end{array}$ \\
\hline HS1 & biała - white & 10,4 & 3,5 & 0,14 \\
\hline HS2 & biała - white & 9,3 & 3,5 & 0,20 \\
\hline HS3 & żółta - yellow & 8,6 & 3,5 & 0,04 \\
\hline HS4 & żółta - yellow & 10,2 & 3,5 & 0,07 \\
\hline HS5 & żółta - yellow & 10,3 & 3,5 & 0,14 \\
\hline
\end{tabular}

\section{Badania właściwości fizykochemicznych koloidów srebra}

Ocena właściwości fizykochemicznych koloidów srebra stabilizowanych hydrolizatami skrobiowymi została przeprowadzona na podstawie widm absorpcyjnych oraz rozkładów wielkości cząstek i obrazów TEM. Cząstki AgNPs poddano analizie dyspersyjnej, podczas której określono rozrzut ich wielkości, wykorzystując metodę nieinwazyjnego wstecznego rozproszenia światła (tzw. metoda NIBS). Dodatkowo określono średnice dominujące cząstek oraz ich udział procentowy w stosunku do całego zakresu zmierzonych cząstek. Każdorazowo pomiary wykonywano trzykrotnie. Rozkład wielkości cząstek zmierzono, używając Zetasizer Nano ZS (Malvern Instruments Ltd.).

Widma absorpcyjne UV-vis, stanowiące analizę jakościową użytego w badaniach nanosrebra, zostały wykonane za pomocą spektrofotometru Ocean Optics UV-vis model USB4000. Do analizy koloidów stabilizowanych hydrolizatami skrobiowymi użyto koloidu o 100-krotnym rozcieńczeniu umieszczonego w kuwecie pomiarowej. Zdjęcie mikroskopowe TEM wykonano za pomocą elektronowego mikroskopu transmisyjnego (ang. transmission electron microscope - TEM) typu Jeol 1200-EX II. Wytworzone koloidy srebra zbadano po 7 dobach, od momentu rozpoczęcia reakcji syntezy.

\section{Badania właściwości bakteriobójczych koloidów srebra}

Przeprowadzono wstępne badania oceniające aktywność bakteriobójczą wytworzonych koloidów srebra. Podłoże agarowe wzbogacone hydrolizatami skrobiowymi (HS1-HS5), dodawanymi w ilości 0,5\%, zaszczepiono tzw. bakteriami bytowymi. Hodowlę prowadzono na płytkach Petriego, w temperaturze $37^{\circ} \mathrm{C}$ przez 7 dni. Badania $\mathrm{w}$ analogicznych warunkach przeprowadzono również dla hodowli bakteryjnych na podłożu agarowym wzbogaconym w nanosrebro stabilizowane badanymi hydrolizatami (100 ppm). 
Sybis, M., Konował, E., Modrzejewska-Sikorska, A. (2017). Bakteriobójcza aktywność koloidów srebra stabilizowanych hydrolizatami skrobiowymi oraz ich wpływ na wytrzymałość zapraw cementowych. Acta Sci. Pol. Architectura, 16 (4), 37-46. doi: 10.22630/ASPA.2017.16.4.04.

\section{Badania wytrzymałościowe zapraw z domieszkami plastyfikatorów oraz koloidów srebra stabilizowanego plastyfikatorami}

Do badań wytrzymałościowych zapraw wykorzystano próbki z zastosowaniem cementu portlandzkiego klasy CEM I 42,5 N zgodnego z normą PN-EN 197-1:2012. Badania te wykonano przy dozowaniu hydrolizatu skrobiowego HS5 w ilości 1,8 g oraz lignosulfonianu sodowego w ilościach 0,15 i 0,30 g na każde $2025 \mathrm{~g}$ zarobu. Badanie wykonano dla zaprawy bez żadnych dodatków (zaprawa referencyjna), zapraw z dodatkiem tylko hydrolizatu i lignosulfonianu oraz zapraw z dodatkiem tych środków wraz $\mathrm{z}$ nanosrebrem $\mathrm{w}$ ilości 100 ppm. Jako kruszywo zastosowano standardowy piasek kwarcowy o frakcjach 0,125-2,00 mm zgodny z normą PN-EN 196-1:2016. Stosunek masowy kruszywa do cementu wynosił 1:3, a stosunek wody do cementu wynosił 0,50 dla wszystkich przeznaczonych do badań próbek. Mieszanki cementowe przygotowano za pomocą automatycznej mieszarki do zapraw cementowych zgodnie z normą PN-EN 196-1:2016.

W celu zbadania wytrzymałości zapraw cementowych, zgodnie z normą PN-EN 196-1: 2016, wykonano beleczki o wymiarach $40 \times 40 \times 160 \mathrm{~mm}$. Świeżą zaprawę bez dodatku plastyfikatorów i koloidów srebra stabilizowanych biopolimerami oraz z ich dodatkiem umieszczono w formach trójdzielnych do zapraw cementowych, zagęszczono przy użyciu wstrząsarki oraz zabezpieczono przed utratą wilgotności.

Próbki po $24 \mathrm{~h}$ od wykonania zarobu zostały rozformowane i umieszczone w wodzie o temperaturze $20-1{ }^{\circ} \mathrm{C}$. Wytrzymałość na ściskanie próbek została zbadana po 28 dniach ich pielęgnacji przy wykorzystaniu prasy wytrzymałościowej firmy Walterbai.

\section{Analizy statystyczne}

Przy użyciu testów statystycznych określono wpływ dodatku srebra i plastyfikatorów na właściwości wytrzymałościowe zapraw cementowych. Wpływ dodatku plastyfikatorów na właściwości zapraw cementowych badano za pomocą testu F jednoczynnikowej analizy wariancji (ANOVA). Wpływ dodatku srebra na właściwości wytrzymałościowe zapraw z dodatkiem plastyfikatorów badano za pomocą testu t-Studenta. Założenie normalności rozkładu sprawdzono testem Shapiro-Wilka, a założenie jednorodności wariancji testem Barletta. Dla wszystkich testów statystycznych przyjęto poziom ufności równy 0,95 .

\section{WYNIKI I DYSKUSJA}

Na postawie uzyskanych rezultatów badań analizy dyspersyjnej koloidów srebra (tab. 2) stwierdzono, że zastosowanie hydrolizatu skrobiowego HS2, HS3 i HS4 pozwoliło uzyskać bardzo małe cząstki AgNPs, których dominująca średnica wyniosła mniej niż $4 \mathrm{~nm}$. Warte odnotowania jest to, że w przypadku tych pochodnych rozrzut wielkości cząstek był również niewielki. Z kolei zastosowanie hydrolizatów HS1 i HS5 doprowadziło do wytworzenia AgNPs o szerokim zakresie wielkości cząstek, od kilkudziesięciu do kilku tysięcy nm, przy czym dominujące średnice nie przekroczyły $40 \mathrm{~nm}$. Obecność dużych cząstek świadczy o możliwości tworzenia się aglomeratów. Spośród wszystkich otrzymanych koloidów srebra najmniejsze średnice cząstek uzyskano dla układu stabilizowanego hydrolizatem skrobiowym HS2.

Potwierdzeniem badań wykonanych techniką NIBS są obrazy uzyskane za pomocą mikroskopu TEM. Na rysunku 1 przedstawiono zdjęcie mikroskopowe TEM dla koloidów srebra stabilizowanych hydrolizatem HS5. Analizując rysunek 1, można zauważyć, że wytworzone cząstki nanosrebra są znacznie mniejsze niż $100 \mathrm{~nm}$, zatem zalicza się je do cząstek nanometrycznych. W pracach Mirzajaniego i innych (2011) oraz Pokrowieckiego i innych (2013) stwierdzono, że nanocząstki srebra o mniejszych rozmiarach mogą być stosowane w znacznie niższych stężeniach, co jest związane $\mathrm{z}$ ich większą reaktywnością. Bardzo ważnym aspektem w badaniach nad bakteriobójczością substancji jest kształt cząstek. Na podstawie badań Wileya, Suna, Mayersa i Xia'ego (2005) oraz Sadeghiego i innych (2012) można stwierdzić, że cząstki o kształtach heksagonalnych, trójkątnych czy o kształtach zbliżonych do nanorurek wykazywały większą skuteczność w działaniach bakteriobójczych 
Sybis, M., Konował, E., Modrzejewska-Sikorska, A. (2017). Bakteriobójcza aktywność koloidów srebra stabilizowanych hydrolizatami skrobiowymi oraz ich wpływ na wytrzymałość zapraw cementowych. Acta Sci. Pol. Architectura, 16 (4), 37-46. doi: 10.22630/ASPA.2017.16.4.04.

Tabela 2. Rozrzut wielkości cząstek koloidów srebra stabilizowanych hydrolizatami HS1-HS5 wraz z możliwymi błędami pomiarów urządzenia

Table 2. Particle size distribution of silver colloids stabilized by HS1-HS5 hydrolysates with measuring device inaccuracies

\begin{tabular}{ccc}
\hline $\begin{array}{c}\text { Próbka } \\
\text { Sample }\end{array}$ & Zakres średnic - Diameter range [nm] & $\begin{array}{c}\text { Średnica dominująca [nm] / Udział objętościowy [\%] } \\
\text { Dominant diameter [nm] / Volume [\%] }\end{array}$ \\
\hline HS1 & $16-122,190-1720,3090-6440$ & $38 / 7,1 \pm 0,2$ \\
\hline HS2 & $2-16$ & $2,3 / 23 \pm 1,5$ \\
\hline HS3 & $2-9,18-51$ & $3,6 / 22,4 \pm 0,4$ \\
\hline HS4 & $1-10,18-38$ & $3,1 / 18,1 \pm 1,4$ \\
\hline HS5 & $18-220,2300-6440$ & $37,8 / 12,4 \pm 1,2$ \\
\hline
\end{tabular}

w porównaniu z nanostrukturami kulistymi. Prawdopodobnie jest to związane $\mathrm{z}$ większą powierzchnią właściwą oddziaływania.

W przeprowadzonych badaniach, analizując rysunek 1, stwierdzono występowanie szerokiego spektrum kształtów nanocząstek, m.in. trójkątów, rombów, struktur heksagonalnych oraz kulistych, co może świadczyć o dużej skuteczności działania bakteriobójczego substancji.

Obecność nanostrukturalnego srebra w wytworzonych układach również potwierdzić można, badając widma UV-vis. Nanocząsteczki srebra (AgNPs) należą do grupy nanochromoforów. Ich cechą charakterystyczną jest pasmo absorpcji przy $\lambda_{\text {max }}=415-450 \mathrm{~nm}$. Wyniki pomiarów zestawiono na rysunku 2 . Każdy z badanych roztworów wykazywał charakterystyczne pasmo absorpcji przy $\lambda=420 \mathrm{~nm}$, przypisywane obecności nanocząstek srebra. Najwyższe stężenie AgNPs odnotowano dla hydrolizatu HS1, a najniższe dla HS5.

Wytworzone przy udziale hydrolizatów skrobiowych nanostruktury srebra wykazały także silne właściwości bakteriobójcze. Na rysunku 3A przedstawiono kolonie bakteryjne wytworzone przez bakterie bytowe po 7 dobach hodowli bez dodatku koloidu, a na rysunku 3B kolonie namnożone na podłożu wzbogaconym w nanosrebro stabilizowane hydrolizatem skrobiowym HS1. Obserwując wyniki poczynionych badań, zaobserwowano, że na próbce referencyjnej wyhodowano kilkadziesiąt kolonii bakteryjnych. Na próbkach zawierających dodatek HS1-HS5, czyli nanosrebro stabilizowane danym

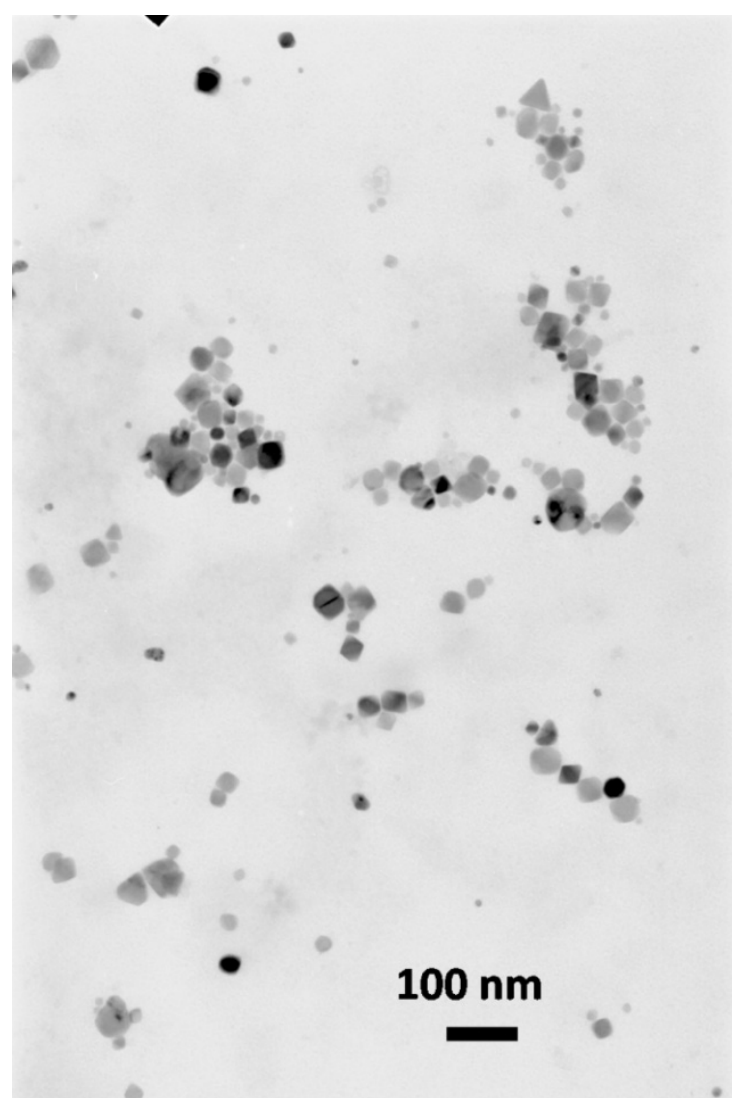

Rys. 1. Obraz spod elektronowego mikroskopu transmisyjnego dla hydrolizatu skrobiowego 5 (HS5)

Fig. 1. Transmission electron microscope image of starch hydrolyzate 5 (HS5) 
Sybis, M., Konował, E., Modrzejewska-Sikorska, A. (2017). Bakteriobójcza aktywność koloidów srebra stabilizowanych hydrolizatami skrobiowymi oraz ich wpływ na wytrzymałość zapraw cementowych. Acta Sci. Pol. Architectura, 16 (4), 37-46. doi: 10.22630/ASPA.2017.16.4.04.

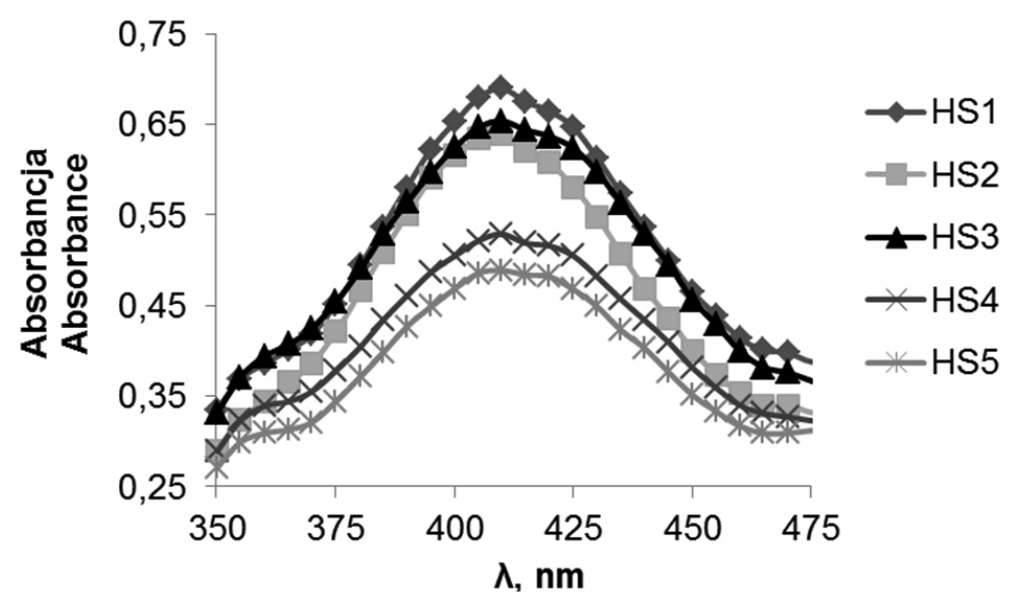

Rys. 2. Widma UV-vis koloidów srebra (HS1-HS5), rozcieńczenie 100×, wyniki po 7 dniach od rozpoczęcia syntezy

Fig. 2. Silver colloids (HS1-HS5) UV-Vis spectra, dilution 100×, results obtained 7 days after the synthesis began
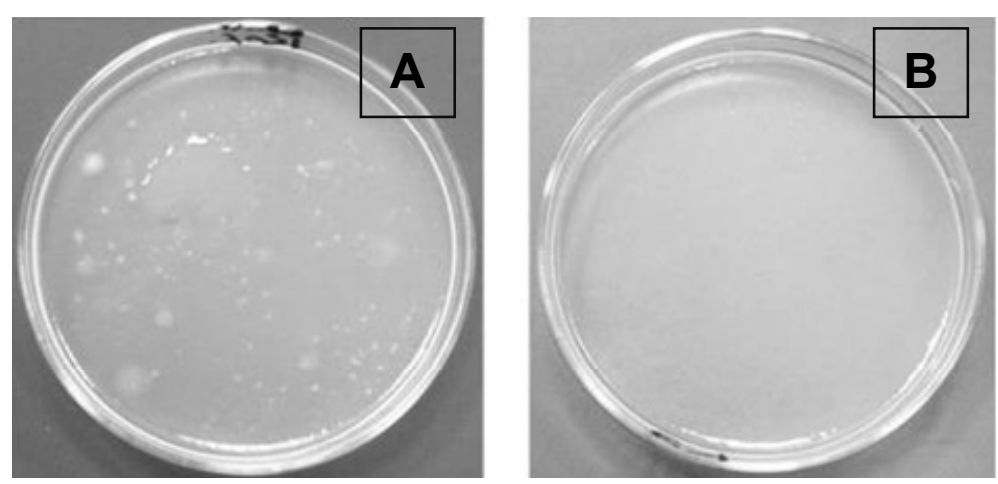

Rys. 3. Bakteriobójcza aktywność koloidów srebra: A - kolonie bakteryjne na podłożu bez dodatku koloidu srebra; B - kolonie bakteryjne na podłożu wzbogaconym w nanosrebro stabilizowane hydrolizatem HS1, dodanym do podłoża w ilości $0,5 \%$

Fig. 3. Bactericidal activity of silver nanoparticles: A - colonies of bacteria on a medium without colloidal silver; B - bacterial colonies on a medium enriched with nanosilver stabilized with HS1 hydrolysate added to the medium at dosage of $0.5 \%$

hydrolizatem skrobiowym, nie wyhodowano zaś żadnych kolonii bakteryjnych. Wytworzone koloidy srebra stabilizowane każdym z przebadanych hydrolizatów cechują się zatem aktywnością biologiczną.

W kolejnym etapie badań przeprowadzono analizę wytrzymałościową, której poddano beleczki z zapraw cementowych z dodatkiem dekstryn z nanosrebrem (rys. 4).

Referencyjna wartość wytrzymałości na ściskanie beleczek cementowych wyniosła 48,5 MPa. Największą wytrzymałość (ok. $55 \mathrm{MPa}$ ) uzyskano dla dodatku HS5 + AgNPs. Najmniejszy wzrost wytrzymałościowy w stosunku do CEM I 42,5 N uzyskano dla $0,15 \mathrm{~g} \mathrm{LS} \mathrm{z} \mathrm{dodatkiem} \mathrm{AgNPs.}$

Powyższe wyniki poddano analizie statystycznej. Wyznaczona za pomocą testu wartość $F_{(3,27)}=14,49$ (wobec wartości krytycznej $\left.F_{k}=2,975\right)$ wskazuje, że przedstawione wyniki różnią się w stopniu znacznym. Przeprowadzono również testy NIR, porównujące wyniki uzyskane dla zapraw z dodatkiem plastyfikatorów z wynikami dla próbek referencyjnych. Wyniki przedstawiono w tabeli 3. 
Sybis, M., Konował, E., Modrzejewska-Sikorska, A. (2017). Bakteriobójcza aktywność koloidów srebra stabilizowanych hydrolizatami skrobiowymi oraz ich wpływ na wytrzymałość zapraw cementowych. Acta Sci. Pol. Architectura, 16 (4), 37-46. doi: 10.22630/ASPA.2017.16.4.04.

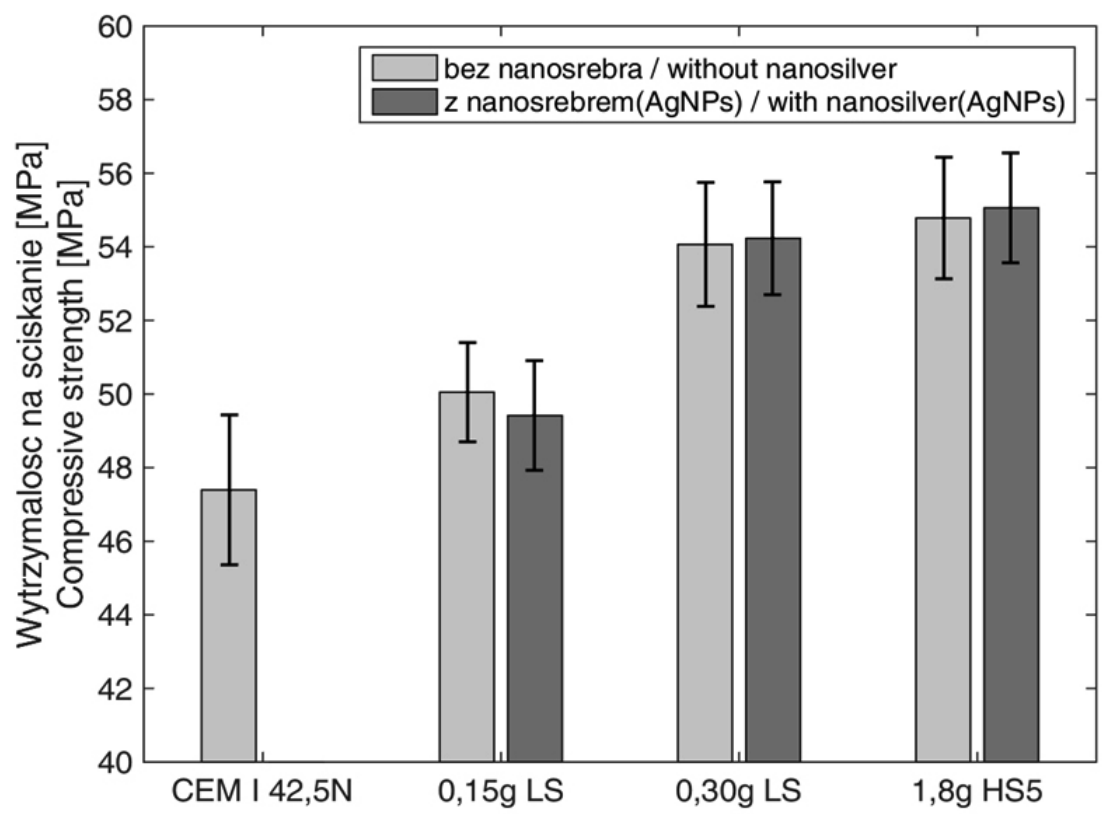

Rys. 4. Średnie wartości (wraz z odchyleniem standardowym) wytrzymałości na ściskanie beleczek z zapraw cementowych z dodatkiem plastyfikatorów handlowych (0,15 LS, 0,30 LS) oraz hydrolizatu skrobiowego 5 (HS5) z dodatkiem i bez dodatku nanosrebra (AgNPs)

Fig. 4. Average (with standard deviation) compressive strength values of cement mortar beams with addition of plasticisers (0.15 LS, 0.30 LS) and a starch hydrolyzate 5 (HS5) with and without nanosilver (AgNPs)

Tabela 3. Wyniki testu najmniejszych istotnych różnic (NIR): porównanie wytrzymałości na ściskanie próbek z dodatkiem plastyfikatora sodowego (0,15 LS, 0,30 LS) i hydrolizatu skrobiowego (HS5) z wytrzymałością próby referencyjnej

Table 3. Results of LSD: post hoc comparison of compressive strength between reference sample, cement mortar beams with addition of plasticizer (0.15 LS, 0.30 LS) and starch hydrolysate (HS5)

\begin{tabular}{ccc}
\hline $\begin{array}{c}\text { Plastyfikator } \\
\text { Plasticizer }\end{array}$ & $\begin{array}{c}\text { Różnica wartości średnich względem wartości referencyjnych } \\
\text { Difference between the considered average values }\end{array}$ & $\begin{array}{c}\text { Wartość NIR } \\
\text { LSD test result }\end{array}$ \\
\hline 0,15 PL & 2,7379 & 2,7126 \\
\hline 0,30 PL & 6,6713 & 2,7126 \\
\hline 1,8 HS5 & 7,3879 & 2,7126 \\
\hline
\end{tabular}

Na podstawie rezultatów zamieszczonych w tabeli 3 można stwierdzić, że średnie wartości wytrzymałości na ściskanie dla próbek z badanymi plastyfikatorami różnią się znacząco od wartości średniej dla próbek referencyjnych.

Porównanie właściwości wytrzymałościowych próbek z dodatkiem plastyfikatorów z takimi samymi próbkami wzbogaconymi dodatkiem srebra wskazuje, że nie różnią się one istotnie. Dodatek nanosrebra nie ma więc wpływu na wytrzymałość beleczek cementowych modyfikowanych dodatkiem plastyfikatora sodowego i hydrolizatu (rys. 4, tab. 4). 
Sybis, M., Konował, E., Modrzejewska-Sikorska, A. (2017). Bakteriobójcza aktywność koloidów srebra stabilizowanych hydrolizatami skrobiowymi oraz ich wpływ na wytrzymałość zapraw cementowych. Acta Sci. Pol. Architectura, 16 (4), 37-46. doi: 10.22630/ASPA.2017.16.4.04.

Tabela 4. Wyniki testów t-Studenta dla próbek z dodatkiem plastyfikatorów sodowych i nanosrebra $(0,15$ PL + AgNPs, 0,30 PL + AgNPs) oraz z dodatkiem hydrolizatu skrobiowego i nanosrebra (HS5 + AgNPs)

Table 4. Student $t$-test results for the cement mortar beams with addition of sodium plasticizer and nanosilver $(0.15 \mathrm{PL}+$ + AgNPs, 0.30 PL + AgNPs) and starch hydrolysate and nanosilver (HS5 + AgNPs)

\begin{tabular}{ccc}
\hline $\begin{array}{c}\text { Plastyfikator + nanosrebro } \\
\text { Plasticizer + nanoparticles }\end{array}$ & $\begin{array}{c}\text { Wynik testu } \\
\text { Test result }\end{array}$ & $\begin{array}{c}\text { Wartość NIR } \\
\text { Follow-up test result }\end{array}$ \\
\hline 0,15 PL + AgNPs & $T=0,51039$ & $|T|<2,2281$ \\
\hline 0,30 PL + AgNPs & $T=-0,032108$ & $|T|<2,2281$ \\
\hline 1,8 HS5 + AgNPs & $T=-0,19449$ & $|T|<2,2281$ \\
\hline
\end{tabular}

Porównując uzyskane wyniki wytrzymałościowe zapraw z domieszkami plastyfikatorów lub hydrolizatów do tych otrzymanych z użyciem AgNPs, można stwierdzić, że zastosowane domieszki mają pozytywny wpływ na wytrzymałość zapraw cementowych. Nie mniej jednak należy stwierdzić, że na wytrzymałość na ściskanie beleczek z zapraw cementowych wpływa głównie dodatek plastyfikatorów.

Przeprowadzone badania wykazały zatem, że sam dodatek nanosrebra nie wpływa znacząco na zmianę parametrów wytrzymałościowych zapraw cementowych zawierających dodatek plastyfikatora sodowego i hydrolizatu skrobiowego. Podkreślić należy, że łącząc ze sobą plastyfikator i nanosrebro, można otrzymać produkt wykazujący zarówno działanie bakteriobójcze, jak i mający wpływ na wzrost wytrzymałości zapraw cementowych. Na podstawie przeprowadzonych wstępnych badań można zatem stwierdzić, że zastosowanie domieszki z nanosrebrem może wpływać na wzrost aktywności bakteriobójczej, jak i na poprawę parametrów fizykochemicznych zapraw cementowych, prawdopodobnie również betonów.

\section{PODSUMOWANIE}

1. W przeprowadzonych badaniach wykazano, że zastosowanie do syntezy biopolimerów HS2, HS3, HS4 pozwala na wytworzenie nanostruktur srebra o średnicach dominujących mniejszych niż $4 \mathrm{~nm}$.

2. Skuteczność bakteriobójcza nanostruktur srebra stabilizowanych hydrolizatami skrobiowymi została potwierdzona podczas hodowli bakterii na podłożu agarowym wzbogaconym o nanosrebro, na którym nie wyhodowano żadnej kolonii bakterii. Na próbce referencyjnej wyhodowano znaczną kolonię bakteryjną.

3. Połączenie zalet plastyfikatorów i nanostrukturalnego srebra daje możliwość wytworzenia preparatu wykazującego zarówno działanie bakteriobójcze, jak i mającego wpływ na wzrost wytrzymałości na ściskanie zapraw cementowych.

\section{PIŚMIENNICTWO}

Alexander, J. W. (2009). History of the medical use of silver. Surgical Infections, 10 (3), 289-292. doi: 10.1089=sur.2008. 9941.

Cho, K. H., Park, J. E., Osaka, T. i Park, S. G. (2005).The study of antimicrobial activity and preservative effects of nanosilver ingredient. Electrochemica Acta, 51 (5), 956-960. doi:10.1016/j.electacta.2005.04.071.

Kanematsu, H. i Yoshitake, M. (2015). Nanocomposite Coating for Antibacterial Purposes. W Handbook of nanoceramic and nanocomposite coating and materials (strony 489-513). Oxford: Elsevier. doi: 10.1016/B978-0-12-7999470.00023-7 
Sybis, M., Konował, E., Modrzejewska-Sikorska, A. (2017). Bakteriobójcza aktywność koloidów srebra stabilizowanych hydrolizatami skrobiowymi oraz ich wpływ na wytrzymałość zapraw cementowych. Acta Sci. Pol. Architectura, 16 (4), 37-46. doi: 10.22630/ASPA.2017.16.4.04.

Konował, E., Modrzejewska-Sikorska, A. i Milczarek, G. (2015). Synthesis and multifunctional properties of lignosulfonate-stabilized gold nanoparticles. Materials Letters, 159, 451-454. doi: 10.1016/j.matlet.2015.07.052.

Milczarek, G., Rebis, T. i Fabianska, J. (2013). One-step synthesis of lignosulfonate-stabilized silver nanoparticles. Colloids and Surfaces. B: Biointerfaces, 105, 335-341. doi: 10.1016/j.colsurfb.2013.01.010.

Mirzajani, F., Ghassempour, A., Aliahmadi, A. i Esmaeili, M. A. (2011). Antibacterial effect of silver nanoparticles on Staphylococcus aureus. Research in Microbiology, 162 (5), 542-549. doi: 10.1007/s10534-010-9381-6.

Oleszkiewicz, A., Korzekwa, K. i Bugia-Płoskońska, G. (2008). Nanocząsteczki w biologii i medycynie. Laboratorium Medyczne, 5, 30-33.

Petica, A., Gavriliu, S., Lungu, M., Buruntea, N. i Panzaru, C. (2008). Colloidal silver solutions with antimicrobial properties. Materials Science and Engineering. B: Solid-state Materials for Advanced Technology, 152 (1-3), 22-27. doi: 10.1016/j.mseb.2008.06.021.

PN-196-1:2006. Metody badania cementu. Część 1. Oznaczanie wytrzymałości.

PN-EN 197-1:2012. Część 1. Skład, wymagania i kryteria zgodności dotyczące cementów powszechnego użytku.

Pokrowiecki, R., Zareba, T., Mielczarek, A., Opalińska, A., Wojnarowicz, J., Majkowski, M., .... i Tyski, S. (2013). Ocena bakteriobójczej aktywności koloidalnego roztworu nanocząstek srebra w stosunku do bakterii próchnicotwórczych. Medycyna Doświadczalna i Mikrobiologia, 65 (3), 197-206. PubMed id: 24432559.

Rai, M., Yadav, A. i Gade, A. (2009). Silver nanoparticles as a new generation of antimicrobials. Biotechnology Advances, 27 (1), 76-83. doi: 10.1016/j.biotechadv.2008.09.002.

Rauwel, P., Rauwel, E., Ferdov, S. I. i Singh, M. P. (2015). Silver nanoparticles: synthesis, properties, and applications. Advances in Materials. Science and Engineering, ID 624394. doi: 10.1155/2015/624394.

Raveendran, P., Fu. J. i Wallen, S. L. (2006). A simple and "green" method for the synthesis of Au, Ag, and Au-Ag alloy nanoparticles. Green Chemistry, 8 (1), 34-38. doi: 10.1039/B512540E.

Sadeghi, B., Garmaroudi, F. S., Hashemi, M., Nezhad, H. R., Nasrollahi, A. i Ardalan, S. (2012). Comparison of the antibacterial activity on the nanosilver shapes: nanoparticles, nanorods and nanoplates. Advanced Powder Technology, 23 (1), 22-26. doi: 10.1016/j.apt.2010.11.011.

Sagripanti, J. L. (1992). Metal-based formulations with high microbicidal activity. Applied and Environmental Microbiology, 58 (9), 3157-3162. id: 0099-2240/92/093157-06\$02.00/0.

Shervani, Z. i Yamamoto, Y. (2011). Carbohydrate-directed synthesis of silver and gold nanoparticles: effect of the structure of carbohydrates and reducing agents on the size and morphology of the composites. Carbohydrate Research, 346, 651-658. doi: 10.1016/j.carres.2011.01.020.

Spear, M. (2010). Silver: an age-old treatment modality in modern times. Plastic Surgical Nursing, 30 (2), 90-93. doi: 10.1097/PSN.0b013e3181deea2e.

Szabó, T., Mihály, J., Sajó, I., Telegdi, J. i Nyikos, L. (2014). One-pot synthesis of gelatin-based, slow-release polymer microparticles containing silver nanoparticles and their application in anti-fouling paint. Progress in Organic Coatings, 77 (7), 1226-1232. doi: 10.1016/j.porgcoat.2014.02.007.

Wiley, B., Sun, Y., Mayers, B. i Xia, Y. (2005). Shape-controlled synthesis of metal nanostructures: the case of silver. Chemistry - A European Journal, 11 (2), 454-463. doi: 10.1002/chem.200400927.

\title{
BACTERICIDAL ACTIVITY OF SILVER COLLOIDS STABILIZED WITH STARCH HYDROLYSATES AND THEIR IMPACT ON STRENGTH OF CEMENT MORTAR
}

\begin{abstract}
The article analyzes silver colloids stabilized with starch hydrolysates for their bactericidal properties as well as determining the size and shape of investigated colloids. The strength properties of cement mortars with the admixtures of the analyzed starch hydrolysates, sodium lignosulfonates and their combination with nanosilver were also investigated. To determine the presence of silver nanostructures, colloidal silver were analyzed
\end{abstract}


Sybis, M., Konował, E., Modrzejewska-Sikorska, A. (2017). Bakteriobójcza aktywność koloidów srebra stabilizowanych hydrolizatami skrobiowymi oraz ich wpływ na wytrzymałość zapraw cementowych. Acta Sci. Pol. Architectura, 16 (4), 37-46. doi: 10.22630/ASPA.2017.16.4.04.

with UV-vis spectrophotometry. The particle size distribution and the shape of nanoparticles were analyzed by non-invasive backscattering light method and transmission electron microscopy (TEM), respectively. The resulting silver colloids showed strong resistance to domestic bacteria. The combination of the aforementioned properties of nanosilver with the plasticizing properties of plasticizers, provides the possibility of producing cement mortars and concretes resistant to microorganisms with significantly improved workability and compressive strength.

Key words: cement paste, silver nanoparticles, bactericidal activity, dextrin, compressive strength 